\title{
Vulnerability and Responses to Risks in Rural India ${ }^{1}$
}

\author{
Raghbendra Jha $^{1}$, Woojin Kang ${ }^{2}$, Hari K. Nagarajan ${ }^{3}$ and Kailash C. Pradhan ${ }^{4}$ \\ ${ }^{1}$ Australian National University, Canberra, Australia, corresponding author r.jha@anu.edu.au \\ ${ }^{2}$ Korea Development Institute, Korea \\ ${ }^{3}$ Institute of Rural Management, Anand, India \\ 4. National Council of Applied Economic Research, India.
}

\begin{abstract}
Using ARIS/REDS data set for 2006 for rural India this paper models household vulnerability as expected utility and its components. We conclude, first, that between the years 1999 and 2006 household vulnerability is most explained by poverty and idiosyncratic components. Second, for risk coping strategy, households rely heavily on informal instrument such as their own saving, transfers or capital depletion. However, they also try to cope with covariate risks by participating in government programmes. Third, household consumption is highly covariate with income. This implies that existing informal insurance instruments are not sufficient to protect household consumption against income shocks. Fourth, a coping strategy using government programmes has vulnerability (idiosyncratic risk component) reducing effects. Finally, there is a strong case for the establishment of strong safety nets in Indian villages. The existing informal strategy is inadequate as a consumption insurance mechanism whereas government programmes are found to reduce vulnerability induced by idiosyncratic shocks. However, access to such programmes is highly constrained. The expansion of suitably designed government programs has the potential of protecting households efficiently from negative shocks.
\end{abstract}

Keywords: Vulnerability as Expected Utility, Coping Strategy, Economic Growth, Social Safety nets

JEL Classification Code: D12, D18, I32, I38

All correspondence to:

Prof. Raghbendra Jha, ASARC, Arndt-Corden Dept of Economics, H.C. Coombs Building (09)

Australian National University, Canberra, ACT 0200, Australia

Phone: + 6126125 2683, Fax: + 6126125 0443,

Email: r.jha@anu.edu.au

\footnotetext{
${ }^{1}$ This paper is part of the IDRC-NCAER research program on "Building Policy Research Capacity for Rural Governance and Growth in India" (grant number 105223). We wish to thank Hans Binswanger and Andrew Foster for comments on earlier drafts. Expert assistance provided by Sudhir Kumar Singh is gratefully acknowledged. The usual caveat applies.
} 


\section{Introduction}

Households in developing countries are often confronted by various types of risks - covariate (e.g. natural disasters, economic or political crisis) and idiosyncratic (e.g. illness of job-loss) shocks. Faced with such risks even non-poor members of society can be vulnerable, if a risky event occurs with ineffective or constrained coping instruments. To better understand the concept of vulnerability, many authors therefore emphasise (i) (exposure to) risks and (ii) instruments for ex ante risk management and ex post risk coping (or resilience) as a response to risks (Chambers, 1989; Alwang, Siegel and Jørgensen, 2001; Heitzmann, Canagarajah and Siegel, 2002; Barrientos, 2007). For example, based on Chambers's distinction between "external" (refers mainly to risks or shocks) and "internal" (refers to the lack of means to manage risks) vulnerability, Alwang et al (2001) and Heitzmann et al (2002) use the term, a 'risk chain' in that those two components lead to (iii) an outcome given by a welfare loss.

Conceptual innovation has been accompanied with a surge of interest in measuring household vulnerability in developing countries (e.g. Kochar, 1999; Dercon and Krishnan, 2000; Chaudhuri, Jalan and Suryahadi, 2002; McCulloch and Calandrino, 2003; Ligon and Schechter, 2003; Gaiha and Imai, 2009; Jha, Dang and Tashrifov, 2010; Kurosaki, 2010). However, many of these papers fall into distinct categories. They either (i) assess vulnerability, or (ii) test risk sharing hypothesis or investigate household risk coping strategy for consumption smoothing. Very few attempts have been made to address these factors in an integrated form. As represented by a 'risk chain' hypothesis, each element is related with other elements. Therefore, to systemically analyse household welfare under risk, one needs to investigate not only households' vulnerability, but also their risk coping strategy and the effect of the strategy on household consumption. For example, even if a household is observed as vulnerable, it may protect itself through the existing coping strategies of which the effects might vary with the nature of the instrument they adopt.

This paper is geared towards addressing these issues for households in rural India. The paper is organized as follows. Section II describes the data used in the empirical analysis. Section III discusses the methodology. Section IV presents the results and section V concludes from a broad policy perspective. 


\section{Data}

The present study draws upon the ARIS/REDS survey of the NCAER. The survey, designed to be a nationally representative multi-purpose rural household and village surveys, was first collected in 1971 and subsequent rounds were conducted in 1982, 1999 and 2006. It consists of listing, household and village questionnaire, collecting detailed household and village information spread across various states in rural India.

The listing section provides information on a number of key household characteristic such as household income and demographics. The household questionnaire surveys information with respect to individual and household characteristics, education, labour participation, detailed incomes by sources, household expenditure, agricultural activities, land and asset ownership. The village survey provides economic and political structure, infrastructure, provision of schools, health service, financial institutions and other social services. Not only for various shocks - both aggregate and idiosyncratic - that households experiences, it also contains detailed information with respect to household coping strategy in the face of the shocks. The numbers of sample households in 1999 and 2006 surveys are 7474 and 8659 households respectively, of which 5883 households were interviewed in both rounds. To analyse household vulnerability, we use a panel households and the final sample size are 5155 due to missing observations. The summary statistics are given in a table in the Appendix.

Although panel data can provide richer information than cross-sectional data, there is a concern with respect to sample attrition. For simple comparison, we construct Table 1 to illustrate the sample size and the distribution across demographical groups for 1999 and 2006 cross-section data, and for panel data. As sample distributions in Table 1 shows, we find no evidence of non-random attrition that could lead to a sample bias problem.

\section{(Table 1 here)}

\section{Methodology}

\subsection{Measuring Vulnerability}


There are several different definitions of vulnerability and each has its own merit. ${ }^{2}$ In the current study we define vulnerability as a household's low expected utility, i.e., vulnerability as expected utility (VEU), proposed by Ligon and Schechter (2003). VEU addresses the weakness of Vulnerability as Expected Poverty (VEP), another popular measure of vulnerability.

Consider two possible states. In the first state, a risk averse household is certain that expected consumption in next period is just below the poverty line. Therefore, the probability of poverty (i.e. vulnerability) in the state is one. In the second state, while its mean expected consumption remains unchanged, there is probability of 0.5 that the household will have consumption just above the poverty line (and above the mean) and probability of 0.5 that the household's consumption will be lower that the mean. Being risk averse, the household would prefer the first state with the certain consumption to the second state with the expected consumption despite lower vulnerability in the second state. This perverse feature of VEP is sought to be overcome by VEU measure (Hoddinott and Quisumbing, 2003). Furthermore, VEU measure decomposes the estimated vulnerability into four distinct components underlying poverty, aggregate shocks, idiosyncratic shocks and unexplained risk.

Vulnerability in the VEU measure is defined as the difference between the utility derived from some level of certainty-equivalent consumption and the expected utility derived from consumption. Therefore, it can be written as follows:

$$
V_{i}=U_{i}(z)-E U_{i}\left(c_{i t}\right)
$$

where $z$ is certainty-equivalent consumption at and above which a household would not be considered vulnerable, analogous to the poverty line. $U_{i}$ is a weakly concave, strictly increasing function.

Eq. (1) can be further decomposed as follows:

$$
\begin{array}{ll}
V_{i}=U_{i}(\mathrm{z})-U_{i}\left(E c_{i t}\right) & \text { (Poverty) } \\
+\left\{U_{i}\left(E c_{i t}\right)-E U_{i}\left[E\left(c_{i t} \mid \bar{X}_{t}\right)\right]\right\} & \text { (Covariate or aggregate risk) }
\end{array}
$$

\footnotetext{
${ }^{2}$ Three major operating definitions of vulnerability can be found in empirical literature: (i) vulnerability as expected poverty (VEP), (ii) vulnerability as low expected utility (VEU) and (iii) vulnerability as uninsured exposure to risk (VER). Hoddinott and Quisumbing (2003) provide an excellent summary of these approaches.
} 


$$
\begin{array}{ll}
+\left\{E U_{i}\left[E\left(c_{i t} \mid \bar{X}_{t}\right)\right]-E U_{i}\left[E\left(c_{i t} \mid \bar{X}_{t}, X_{i t}\right)\right]\right\} & \text { (Idiosyncratic risk) } \\
+\left\{E U_{i}\left[E\left(c_{i t} \mid \bar{X}_{t}, X_{i t}\right)\right]-E U_{i}\left(c_{i t}\right)\right\} & \text { (Unexplained risk \& Measurement error) }
\end{array}
$$

As in Ligon and Schechter (2003), the following form of utility function is assumed:

$$
U(c)=\frac{c^{1-\kappa}}{1-\kappa}
$$

where $\kappa$ denotes the household coefficient on relative risk aversion and is set to 2 .

We also normalise expenditure and per capita income so that the average expenditure and per capita income over all households would be unity and set poverty line to be one by choosing $z$ equals average consumption. ${ }^{3}$ Therefore, household vulnerability will be zero if resources are allocated so that households receive the expected consumption expenditure with certainty (Ligon and Schechter, 2003).

$E\left(c_{i t} \mid \bar{X}_{t}\right)$ in the aggregate risk component and $E\left(c_{i t} \mid \bar{X}_{t}, X_{i t}\right)$ in the idiosyncratic risk component are estimated by:

$$
\begin{aligned}
& E\left(c_{i t} \mid \bar{X}_{t}\right)=\alpha_{i}+\eta_{t} \\
& E\left(c_{i t} \mid \bar{X}_{t}, X_{i t}\right)=\alpha_{i}+\eta_{t}+\beta X_{i t}
\end{aligned}
$$

In Eq. (5), if income is used as the explanatory variable for consumption (as in our case), it might be endogenous. For example, saving and liquidation of household assets (e.g. livestock) are likely to influence income as well as consumption since parts of assets are used for production (Gaiha and Imai, 2009). Hence, we use the instrumental variable (IV) estimation for Eq. (5) in which income is treated as being endogenous.

\subsection{Household response to risks - choice of coping strategy}

As stated earlier, households' income and consumption fluctuate due to various risks - both aggregate and idiosyncratic shocks, and such fluctuations make households vulnerable, often compounded by the lack of (or incomplete) credit or insurance markets. To protect

\footnotetext{
${ }^{3}$ Household consumption expenditure and income in 2006 data were adjusted at 1999 value using state wise CPI for agriculture and rural labourers.
} 
themselves from such unexpected shocks, households are keen to manage risks ex ante (e.g. income smoothing such as crop diversification) or cope with the consequences of the risks ex post (e.g. consumption smoothing through precautionary saving or transfer etc.).

To investigate households' response to shocks, the multivariate probit model is applied here because households often choose different coping instrument at the same time in the face of risks and the model allows correlation between such choices:

The latent decision variable for coping instruments $R_{i m}^{*}$ is assumed to be a function of household characteristics, $X_{i m}$ and an error terms $\varepsilon_{i m}$.

$$
R_{i m}^{*}=\vartheta_{m} X_{i m}+\varepsilon_{i m}
$$

The error term $\varepsilon_{i m}$ has multivariate normal distribution, with zero mean and variancecovariance matrix $V$, where $V$ has values of 1 on the leading diagonal and correlations $\rho_{m n}=\rho_{n m}$ as off-diagonal elements (Cappellari and Jenkins, 2003).

$$
R_{i m}=1 \text { if } R_{i m}^{*}>0 \text {, and } 0 \text { otherwise }
$$

As a household decision on coping strategies relies on not only household characteristics but also the nature of the risks it faces, a vector of shock variables (dummy) is included in the model. These are: (i) aggregate (drought, floods, livestock epidemic, and epidemic) and idiosyncratic (death of household members, health problems, and crop failure) shocks. The estimation is carried out, drawing upon 2006 data only due to the lack of information on the coping mechanism in 1999.

For household coping strategy against shocks, we classified household responses into 5 categorises: (i) Saving, (ii) the government program, (iii) Borrowing/Transfer, (iv) Capital depletion and (v) other responses.

\subsection{Measure of consumption insurance}

Although household attempt to manage their ex ante or ex post responses by formal and informal risk management schemes (e.g. precautionary saving, mutual insurance etc.) the extent of consumption smoothing depends on the quality of the existing mechanism. One way to investigate the effectiveness of the mechanism is to estimate the following specification: 


$$
\Delta \ln c_{i v t}=\phi+\gamma \Delta \ln y_{i v t}+\psi \Delta\left(\overline{\ln y_{v t}}\right)+\delta X_{i v t}+\Delta \varepsilon_{i v t}
$$

where $\Delta \ln c_{i v t}$ and $\Delta \ln y_{i v t}$ denote the growth rate of household consumption and income respectively. $\Delta\left(\overline{\ln y_{v t}}\right)$ represents the growth rate of average village (or state) income and is treated as a proxy of aggregate shocks (Townsend, 1994)

The estimate of $\gamma$ on which much of the empirical literature focuses indicates whether insurance mechanism takes an effect within villages (states). If complete insurance or risk sharing exists, $\gamma$ is expected to be zero and significant. Thus, the higher values of $\gamma$ would be an evidence of weak consumption insurance against income risks. ${ }^{4}$

As a measure of welfare, food consumption is frequently used in regions where a substantial fraction of the population devotes more than three quarters of their expenditure to food (Deaton, 1997). In such a society, households are expected to be conservative in maintaining the level of consumption expenditure and hence, expenditure devoted to food is likely to be less covariate with income than other components of expenditure as often reflected by Engel curve in developing countries.

Our data also show that the shares of food consumption to total consumption expenditure are quite high (57.7\% in 1999 and 53.8\% in 2006) and these high shares suggest the possibility that household might keen to insure their food consumption against negative shocks. Therefore, we will use three different dependent variables (total consumption, food consumption, non-food consumption expenditure).

\section{Result}

\section{(a) Measure of VEU}

Table 2 shows the result from estimation in Eq. (4).

\section{(Table 2 here)}

\footnotetext{
${ }^{4}$ We interpret $\gamma$ as a measure of consumption insurance rather than a measure of vulnerability as done in VER measure. VER model assumes that positive and negative shocks have symmetric effects. However, ability in dealing with positive shocks (e.g. accumulating assets or saving etc.) compared to negative shocks (selling assets or receiving transfers etc.) is likely to different across households. Therefore, in order to interpret $\gamma$ as a measure of vulnerability it is suggested to replace $\Delta \ln y_{\text {ivt }}$ with two covariates denoting absolute values of the size of positive and negative income changes (Hoddinott and Quisumbing, 2003).
} 
The coefficient estimate, negative and strongly significant, of time dummy for year 1999 indicates that aggregate risk is mostly explained by a positive shock. i.e., rural India has enjoyed economic growth between 1999 and 2006. We also observed that households in a reserved village would have higher per capita consumption expenditure relative to those in a village never reserved though the coefficient is found to be significant for the twice reserved village. The dummy variables of agro climatic condition (Arid region is the reference) show that humid and semi-arid tropic are positively associated with household consumption. ${ }^{5}$

Table 3 provides the result obtained from Panel IV estimation for Eq. (5). Income is instrumented in the first stage by the per capita number of productive assets (e.g. tractors) and the share of the area of irrigated land to total land a household owned. Although the possible effects of these variables on household consumption cannot be denied, it might be reasonable that they first affect household income. Same type of instruments for income is also specified in Gaiha and Imai (2009) and Jha et al (2010). As shown from the Table 3, Hansen-Sargan statististic of overidentification test indicates that the instruments used here are valid.

\section{(Table 3 here)}

In the first stage estimation, female headship is positively associated with a household's income and its coefficient is significant at the 5\% level. In contrast, the coefficient estimate of female share is negative and strongly significant, implying that a household with many female members tends to have lower per capita income. This may suggest that although high economic growth took place during a period of 1999-2006, less economic opportunities for women were generated. The positive and significant coefficient estimate of its square term suggests the non-linear association between the share of female members and per capita household income. We cannot find any evidence of life cycle effect, which is partly captured by the age of a household and its square term. The negative coefficient of share of members with high secondary or higher education, and the positive coefficient of its square term suggests that although education has a positive impact on household income, relationship is shown to be convex. Table 3 also shows strong evidence of a hump-shaped relationship between a household's productive assets and household income. As expected, the higher share of irrigated land to total land would increase a household's per capita income.

\footnotetext{
${ }^{5}$ The present study uses ICRISAT definition of agro climatic condition. Classification is given in summary statistics in Appendix.
} 
Turning to the second stage estimation, the size of coefficient estimate, strongly significant at $1 \%$ level, of the predicted per capita income suggests that household consumption is determined largely by its income. The negative and significant coefficient estimate of dependency implies that a household with many old or young members tend to have lower per capita consumption expenditure. The higher share of educated members, the higher is per capita consumption and we find no evidence of non-linear effect on consumption whereas strong non-linearity is observed in the first stage income estimation. The availability of public goods is positively associated with household consumption with the coefficient significant at $5 \%$. This, together with the negative association, though insignificant, between public goods and household income, implies that the provision of public goods tends to promote household consumption but not necessarily household income. The positive and strongly significant both economically and statistically - coefficient estimates of humid and semi-arid regional dummies suggest climatic condition is an important factor determining the level of household consumption.

The results obtained from Eq. (4) and (5) were used to derive VEU. We then decomposed the average VEU into 4 distinct components as discussed earlier. These components are shown in Table 4.

\section{(Table 4 here)}

The estimate of average VEU (0.3016) implies that rural Indian households have experienced about $30 \%$ of utility loss due to poverty (e.g. low physical and human capitals) or inequality, and various risks during 1999-2006. The negative sign of covariate risk component suggests that the utility loss would have been higher if there had been no economic growth in rural India during the sample period. Offsetting the impact of economic growth, it is observed from Table 4 that average household vulnerability during 1999-2006 mainly originated from low levels of living standards and and idiosyncratic shocks.

\section{(b) Household response to risks-Coping strategies}

Table 5 provides the results obtained from multivariate probit estimation, drawing upon 2006 survey, to investigate the choice of household coping strategy. Panel (A) uses idiosyncratic and covariate shock in the aggregate level whereas panels (B) and (C) use the shock variables 
at the disaggregated level. ${ }^{6}$ The other explanatory variables used in the model are same as in Table $3 .^{7}$ We used Huber-White sandwich estimator to overcome heteroskedasticity.

\section{(Table 5 here)}

Summary of findings are given below. ${ }^{8}$ We first observe from panels A and B that the main coping mechanism of rural Indian households is withdrawal of own saving. Regardless of model specifications based on the types of shocks used, savings withdrawal has the highest probability of occurrence among the defined household coping strategies. Second, panel (A) shows that households are likely to choose borrowing or transfer from its relatives or friends in the face of idiosyncratic shocks whereas it relies on capital depletion when it faces covariate shocks. ${ }^{9}$ This choice of coping strategy seems to be sensible in that as covariate shocks affects other residents within village as well as the household under consideration and makes it less likely for the household to rely on transfer as a coping strategy. Therefore, the household would be forced to sell its assets, reduce consumption or withdraw children from school. Similar findings are also observed from panel (B) where disaggregated shocks variables are included. Third, although a household is less likely to choose a government provided coping programme when it faces idiosyncratic shock, the probability sharply increases if it is affected by covariate shock (both coefficient estimates of idiosyncratic and covariate shocks in the government programme are significant in Panel (A)). However, when we use each of specific type of shock variables, the coefficient estimates of idiosyncratic shocks in the government programme become insignificant while those of covariate shocks are still significant. Comparing the probability of choice of the government programme with those of other coping strategies, rural Indian households manage risks using their own means or by informal strategies.

\footnotetext{
${ }^{6}$ For example, if a household has experienced any of the following shocks - drought, floods, livestock epidemic and epidemic - then the dummy of covariate shock in panel (A) takes the value one. Similarly, idiosyncratic shock takes the value of one if the household has in the past faced either death of its member(s), sudden health problem or crop failure.

${ }^{7}$ For the sake of convenience, we provide the results with respect to shocks variables and public goods, which are the main focus of our estimation. The full table will be furnished upon request.

${ }^{8}$ Full results will be furnished upon request.

${ }^{9}$ Capital depletion is said to occur if a household chooses, as a coping strategy, to sell assets, withdraw children from school, reduce consumption or change crop choice. The elements of capital depletion would all affect household future income. For example, reducing consumption would lower labour productivity through inadequate nutrition intake. Change in crop choice would also result in low risk and low expected income. Therefore, these strategies are aggregated as capital depletion as its consequence is likely to be different from other coping strategies.
} 


\section{(c) Measure of consumption insurance}

Since Table 5 only provides household response to risks and not whether the household could effectively insure their consumption, we estimate Eq. (8) for the measure of insurance and using IV techniques. The results are given in Table 6. As in Table 3, the change of household income was treated as endogenous and was instrumented by the change in per capita productive assets, its square and the change in the share of irrigated land. Estimations were carried out at the village level. The upper panel of Table 6 presents the results of first stage estimation of IV estimation whereas the lower panel show second stage estimation. The results of Diagnostic tests (e.g. Durbin-Wu-Hausman test for endogeneity) support the use of IV estimation and instruments.

\section{(Table 6 here)}

As noted earlier, if complete insurance or risk sharing existed within villages the coefficient estimates of the change in log of household income would equal zero and be significant, and that of the change in village mean of log income would be non-zero and significant. Although complete risk sharing is often rejected, much of empirical literature has observed partial risk sharing within villages (e.g. Townsend, 1994). Our results show that the growth of consumption is highly covariate with the growth of income, suggesting that although households rely mainly on informal risk coping instruments, those strategies adopted by households are less effective. Furthermore, the negative and significant coefficient estimate in the change of village mean of log income suggests that there is no risk sharing mechanism within villages. ${ }^{10}$

The constrained access to efficient risk management mechanisms among households implies the risk of increase in the rural transient poor in the face of shocks. Further, our finding from the multivariate probit model (Table 5) that one of the significant household's coping strategies is capital depletion - selling productive assets, reducing consumption or withdrawal of children from school - might have long term consequences on household welfare, and may trap them in poverty.

\footnotetext{
${ }^{10}$ As our results are based on rural representative data, they are not necessarily at variance with the finding of partial risk sharing in other studies many of which draw upon selected sample village data for annual consumption and income. Our results are similar to the findings of Shirapur and Kanzara villages in Gaiha and Imai (2009).
} 
Comparing the coefficient estimates in food consumption and non-food consumption estimations (the second vs. the third columns), the smaller coefficient estimates of the change of log income in food consumption (though the difference is not large) is likely to suggest that households are keener to insure food consumption than non-food consumption when faced with income shocks.

\section{V.Policy implications and conclusions}

The results in this paper warrant the following conclusions. First, between the years 1999 and 2006 household vulnerability is most explained by poverty and idiosyncratic components. Second, for risk coping strategy, households rely heavily on informal instrument such as their own saving, transfers or capital depletion. However, they also try to cope with covariate risks by participating in government programmes. Third, household consumption is highly covariate with income. This implies that existing informal insurance instruments are not sufficient to protect household consumption against income shocks. Fourth, a coping strategy using government programmes has vulnerability (idiosyncratic risk component) reducing effects. Finally, there is a strong case for the establishment of strong safety nets in Indian villages. The existing informal strategy is inadequate as a consumption insurance mechanism whereas government programmes are found to reduce vulnerability induced by idiosyncratic shocks. However, access to such programmes is highly constrained. The expansion of suitably designed government programs has the potential of protecting households efficiently from negative shocks. 


\section{Reference}

Alwang, J. Siegel, P. B. and S. L. Jørgensen (2001) 'Vulnerability: A View from Different Disciplines' Social Protection Discussion Paper Series No. 0115, The World Bank.

Barrientos, A. (2007) 'Does Vulnerability Create Poverty Traps?' CPRC Working Paper No.76.

Becker, S. and A. Ichino (2002) 'Estimation of Average Treatment Effects based on Propensity Scores’ The Stata Journal, 2(4), pp. 358-377.

Cappellari, L., and S. P. Jenkins (2003) 'Multivariate Probit Regression Using Simulated Maximum Likelihood' The Stata Journal, 3(3), pp. 278-294.

Chambers, R. (1989) Editorial Introduction: Vulnerability, Coping and Policy, Institute of Development Studies Bulletin, 20(2), p.1-7.

Chaudhuri, S., Jalan J. and A. Suryahadi (2002) 'Assessing Household Vulnerability to Poverty: A Methodology and Estimates for Indonesia' Discussion Paper, No. 0102-52, Columbia University.

Deaton, A. (1997) The Analysis of Household Surveys: A Microeconometric Approach to Development Policy, Baltimore and London: The Johns Hopkins University Press.

Dercon, S., and P. Krishnan (2000) 'In Sickness and in Health: Risk-Sharing within Households in Rural Ethiopia' Journal of Political Economy, 108, pp. 688-727.

Gaiha, R., and K. Imai (2009) 'Measuring Vulnerability and Poverty in Rural India' I W. Naudé, A. Santos-Paulino and M. McGillivray (Eds.) Vulnerability in Developing Countries, UNU-WIDER, United Nation University Press.

Heitzmann, K., Canagarajah, R. S., and P.B. Siegel (2002) 'Guidelines for Assessing the Sources of Risk and Vulnerability' Social Protection Discussion Paper Series No. 0218, The World Bank.

Hoddinott, J., and A. Quisumbing. (2003) 'Methods for Microeconometric Risk and Vulnerability Assessments' Social Protection Discussion Paper Series No.0324, The World Bank.

Jha, R., Imai, K., and R. Gaiha (2009) 'Poverty, Undernutrition and Vulnerability in Rural India: Public Works versus Food Subsidy’ CPRC Working Paper No. 135.

Jha, R., Dang, T., and Y. Tashrifov (2010) 'Economic Vulnerability and Poverty in Tajikistan' Economic Change and Restructuring, 43(2), pp. 95-112.

Kochar, A. (1999) 'Smoothing Consumption by Smoothing Income: Hours-of-Work Responses to Idiosyncratic Agricultural Shocks in Rural India' The Review of Economics and Statistics, 81(1), pp. 50-61. 
Kurosaki, T. (2010) 'Targeting the Vulnerable and the Choice of Vulnerability Measure: Review and Application to Pakistan' PRIMCED Discussion Paer Series No.1.

Ligon, E and L. Schechter (2003) 'Measuring Vulnerability' The Economic Journal, 113, pp. 95-102.

McCulloch, N. and M. Calandrino (2003) 'Vulnerability and Chronic Poverty in Rural Sichuan’ World Development, 31(3), pp. 611-628

Swain, R.B., and M. Floro (2010) 'Reducing Vulnerability through Microfinance: Evidence from Indian Self Help Group Program’ Working Paper 2010:23, Uppsala University.

Townsend, M. R. (1994) 'Risk and Insurance in Village India' Econometrica, 62, pp. 539591. 
Table 1: Sample size and Distribution

\begin{tabular}{|c|c|c|c|c|}
\hline & \multicolumn{2}{|c|}{ Cross-Section } & \multicolumn{2}{|c|}{ Panel } \\
\hline & 1999 & 2006 & 1999 & 2006 \\
\hline Total observations & 7474 & 8659 & 5883 & 5883 \\
\hline Household head age & & & & \\
\hline Less than 30 & 9.6 & 5.5 & 9.0 & 4.7 \\
\hline $31-40$ & 24.2 & 20.8 & 23.2 & 20.1 \\
\hline $41-50$ & 23.5 & 27.9 & 23.8 & 27.7 \\
\hline $51-60$ & 20.6 & 22.0 & 22.4 & 22.0 \\
\hline $61-70$ & 15.8 & 16.8 & 16.5 & 17.7 \\
\hline Greater than 70 & 6.3 & 7.1 & 5.1 & 7.8 \\
\hline Male head (\%) & 93.4 & 89.4 & 94.5 & 90.0 \\
\hline Female head (\%) & 6.6 & 10.6 & 5.5 & 10.0 \\
\hline Head married (\%) & 87.9 & 86.5 & 88.1 & 86.8 \\
\hline Unmarried $\quad(\%)$ & 12.1 & 13.5 & 11.9 & 13.2 \\
\hline ST household (\%) & 12.71 & 16.51 & 13.19 & 14.64 \\
\hline SC household (\%) & 6.48 & 8.11 & 4.84 & 7.55 \\
\hline OBC household (\%) & 47.46 & 46.63 & 48 & 47.03 \\
\hline OC household (\%) & 33.36 & 28.75 & 33.97 & 30.78 \\
\hline Hindu (\%) & 88.5 & 88.6 & 89.6 & 88.8 \\
\hline Muslim (\%) & 6.9 & 6.0 & 6.0 & 5.8 \\
\hline Sikh (\%) & 2.8 & 3.3 & 2.9 & 3.2 \\
\hline Christian (\%) & 1.4 & 1.5 & 1.2 & 1.5 \\
\hline Jain (\%) & 0.03 & 0.2 & 0.02 & 0.2 \\
\hline Buddhist (\%) & 0.4 & 0.4 & 0.4 & 0.4 \\
\hline
\end{tabular}

Source: REDS 1999 and 2006 
Table2: Covariate risk component (Panel Random effect)

\begin{tabular}{|c|c|}
\hline & Per capita household consumption \\
\hline \multirow[t]{2}{*}{ yr99 } & -0.125 \\
\hline & $(11.59)^{* * *}$ \\
\hline \multirow[t]{2}{*}{ once_res } & 0.029 \\
\hline & $(1.14)$ \\
\hline \multirow[t]{2}{*}{ twice_res } & 0.058 \\
\hline & $(1.87)^{*}$ \\
\hline \multirow[t]{2}{*}{ Humid area } & 0.201 \\
\hline & $(2.18) * *$ \\
\hline \multirow[t]{2}{*}{ Semi-Arid temperate } & 0.071 \\
\hline & $(0.61)$ \\
\hline \multirow[t]{2}{*}{ Semi-Arid tropic } & 0.229 \\
\hline & $(2.15)^{* *}$ \\
\hline \multirow[t]{2}{*}{ Constant } & 0.862 \\
\hline & $(9.09)$ \\
\hline Observations & 11727 \\
\hline R-squared & 0.03 \\
\hline \multirow[t]{2}{*}{ Observations } & 11729 \\
\hline & $\mathrm{F}(6,5839)$ \\
\hline Joint significance & $=30.52$ \\
\hline Prob $>$ chi2 & 0.0000 \\
\hline \multirow{2}{*}{$\begin{array}{l}\text { Hausman Test: fixed } \\
\text { vs. random effect }\end{array}$} & $\operatorname{chi} 2(6)=73.54$ \\
\hline & Prob $>$ chi $2=0.0000$ \\
\hline \multicolumn{2}{|c|}{ Absolute value of $t$ statistics in parentheses } \\
\hline \multicolumn{2}{|c|}{$*$ significant at $10 \% ; * *$ significant at $5 \% ; * * *$ significant at $1 \%$} \\
\hline \multicolumn{2}{|c|}{ 1. village never reserved is the reference group } \\
\hline \multicolumn{2}{|c|}{$\begin{array}{l}\text { 2. Arid area is the reference group } \\
\text { Source: REDS } 1999 \text { and } 2006\end{array}$} \\
\hline
\end{tabular}


Table 3: Idiosyncratic risk component (Panel fixed effects IV model)

\begin{tabular}{|c|c|c|}
\hline & $\begin{array}{l}\text { First stage } \\
\text { p. c. income }\end{array}$ & $\begin{array}{c}\text { Second stage } \\
\text { p.c. consumption }\end{array}$ \\
\hline lpcincome & & $\begin{array}{c}0.408 \\
(11.12)^{* * *}\end{array}$ \\
\hline fhead & $\begin{array}{c}0.212 \\
(2.00)^{* *}\end{array}$ & $\begin{array}{l}-0.042 \\
(0.79)\end{array}$ \\
\hline age & $\begin{array}{l}0.013 \\
(1.06)\end{array}$ & $\begin{array}{l}-0.008 \\
(1.32)\end{array}$ \\
\hline age2 & $\begin{array}{l}0.000 \\
(0.82)\end{array}$ & $\begin{array}{c}0 \\
(1.09)\end{array}$ \\
\hline femaleshare & $\begin{array}{c}-2.553 \\
(3.51)^{* * *}\end{array}$ & $\begin{array}{l}0.418 \\
(1.09)\end{array}$ \\
\hline femaleshare 2 & $\begin{array}{c}2.578 \\
(3.76)^{* * *}\end{array}$ & $\begin{array}{l}-0.574 \\
(1.56)\end{array}$ \\
\hline dependency & $\begin{array}{l}-0.124 \\
(1.12)\end{array}$ & $\begin{array}{c}-0.242 \\
(4.34)^{* * *}\end{array}$ \\
\hline seconedushare & $\begin{array}{l}-1.144 \\
(4.94)^{* * *}\end{array}$ & $\begin{array}{c}0.236 \\
(1.86)^{*}\end{array}$ \\
\hline seconedushare2 & $\begin{array}{c}0.944 \\
(4.48)^{* * *}\end{array}$ & $\begin{array}{l}-0.035 \\
(0.31)\end{array}$ \\
\hline yr99 & $\begin{array}{l}-0.133 \\
(1.88)^{*}\end{array}$ & $\begin{array}{l}0.052 \\
(1.44)\end{array}$ \\
\hline pubgoods_hh & $\begin{array}{l}-0.009 \\
(1.07)\end{array}$ & $\begin{array}{c}0.01 \\
(2.50)^{* *}\end{array}$ \\
\hline once_res & $\begin{array}{l}0.120 \\
(1.55)\end{array}$ & $\begin{array}{l}0.023 \\
(0.61)\end{array}$ \\
\hline twice_res & $\begin{array}{c}0.280 \\
(2.89)^{* * *}\end{array}$ & $\begin{array}{l}-0.008 \\
(0.17)\end{array}$ \\
\hline Humid & $\begin{array}{l}-0.233 \\
(0.82)\end{array}$ & $\begin{array}{c}0.432 \\
(3.09)^{* * *}\end{array}$ \\
\hline SA_temperate & $\begin{array}{l}-0.015 \\
(0.04)\end{array}$ & $\begin{array}{l}0.233 \\
(1.28)\end{array}$ \\
\hline SA_tropic & $\begin{array}{l}-0.243 \\
(0.74)\end{array}$ & $\begin{array}{c}0.428 \\
(2.64)^{* * *}\end{array}$ \\
\hline pcasset & $\begin{array}{c}0.227 \\
(13.19)^{* * *}\end{array}$ & \\
\hline (pcasset)2 & $\begin{array}{c}-0.001 \\
(11.03)^{* * *}\end{array}$ & \\
\hline land_irrigate & $\begin{array}{c}0.189 \\
(2.94)^{* * *}\end{array}$ & \\
\hline Constant & $\begin{array}{l}1.001 \\
(2.04) \\
\end{array}$ & $\begin{array}{l}0.266 \\
(1.05) \\
\end{array}$ \\
\hline Observations & & \\
\hline Joint significance & $\begin{array}{c}\mathrm{F}(18,4959) \\
=20.02 \\
\text { Prob }>\mathrm{F}=0.0000 \\
\end{array}$ & $\begin{array}{c}\text { Wald chi } 2(16) \\
=18406.58 \\
\text { Prob }>\text { chi } 2=0.0000\end{array}$ \\
\hline Hausman Test: fixed effects vs. random effect & \multicolumn{2}{|c|}{$\begin{array}{l}\text { Wald chi } 2(15)=34.63 \\
\text { Prob }>\text { chi } 2=0.0028\end{array}$} \\
\hline $\begin{array}{l}\text { Sargan-Hansen test for } \\
\text { overidentification restriction }\end{array}$ & & \\
\hline
\end{tabular}


Table 4: Decomposition of average vulnerability

\begin{tabular}{|c|c|c|c|c|c|c|c|c|}
\hline VEU & $=$ & Poverty & + & $\begin{array}{l}\text { Covariate } \\
\text { risk }\end{array}$ & + & $\begin{array}{c}\text { Idiosyncratic } \\
\text { risk }\end{array}$ & + & $\begin{array}{c}\text { Unexplained } \\
\text { risk }\end{array}$ \\
\hline 0.3016 & & 0.2103 & & -0.1996 & & 0.196 & & 0.0949 \\
\hline
\end{tabular}

Source: REDS 1999 and 2006

Table 5: Multivariate Probit model: Household coping strategy (Shock variables - Dummy)

\begin{tabular}{|c|c|c|c|c|c|}
\hline HH coping strategy & Saving & Government & Transfer & Capital depletion & Other \\
\hline & \multicolumn{5}{|c|}{ Panel (A) } \\
\hline \multirow[t]{2}{*}{ Idiosyncratic } & 1.516 & 0.239 & 0.825 & 0.505 & -2.553 \\
\hline & $(28.63)^{* * *}$ & $(3.46)^{* * *}$ & $(14.58) * * *$ & $(9.12)^{* * *}$ & $(27.72) * * *$ \\
\hline \multirow[t]{3}{*}{ Covariate } & 1.626 & 0.873 & 0.326 & 0.948 & -2.608 \\
\hline & $(35.11)^{* * *}$ & $(12.87)^{* * *}$ & $(6.45)^{* * *}$ & $(18.15)^{* * *}$ & $(30.14)^{* * *}$ \\
\hline & \multicolumn{5}{|c|}{ Panel (B) } \\
\hline \multirow[t]{2}{*}{ Death } & 1.516 & -0.004 & 0.362 & 0.122 & -1.919 \\
\hline & $(14.39)^{* * *}$ & $(0.03)$ & $(3.99)^{* * *}$ & (1.09) & $(15.26) * * *$ \\
\hline \multirow[t]{2}{*}{ Health } & 1.363 & -0.015 & 0.891 & 0.213 & -2.252 \\
\hline & $(14.59)^{* * *}$ & $(0.10)$ & $(10.16)^{* * *}$ & $(2.10)^{* *}$ & $(14.02)^{* * *}$ \\
\hline \multirow[t]{2}{*}{ Cropfail } & 0.982 & 0.086 & 0.205 & 0.599 & -1.468 \\
\hline & $(12.21)^{* * *}$ & $(0.80)$ & $(2.49)^{* *}$ & $(7.74)^{* * *}$ & $(14.43)^{* * *}$ \\
\hline \multirow[t]{2}{*}{ Drought } & 1.329 & 0.125 & 0.333 & 0.603 & -1.906 \\
\hline & $(23.76)^{* * *}$ & $(1.65)^{*}$ & $(5.56)^{* * *}$ & $(10.66)^{* * *}$ & $(23.15)^{* * *}$ \\
\hline \multirow[t]{2}{*}{ Floods } & 1.089 & 0.99 & 0.076 & 0.898 & -2.155 \\
\hline & $(16.45)^{* * *}$ & $(14.08)^{* * *}$ & $(1.06)$ & $(14.24)^{* * *}$ & $(21.03) * * *$ \\
\hline \multirow[t]{2}{*}{ Livestk } & 1.265 & 0.543 & 0.605 & 0.295 & -1.799 \\
\hline & $(9.15)^{* * *}$ & $(3.64) * * *$ & $(5.68)^{* * *}$ & $(2.30)^{* *}$ & $(9.95) * * *$ \\
\hline \multirow[t]{2}{*}{ Epidemic } & 0.761 & -0.338 & -0.439 & 0.267 & 0.046 \\
\hline & $(5.47)^{* * *}$ & $(1.26)$ & $(2.70)^{* * *}$ & $(2.04)^{* *}$ & $(0.29)$ \\
\hline Observations & 5,558 & 5,558 & 5,558 & 5,558 & 5,558 \\
\hline Joint significance & \multicolumn{5}{|c|}{ (A) $\operatorname{chi} 2(65)=4765.61,(\mathrm{~B}) \operatorname{chi} 2(75)=3752.18,(\mathrm{C}) \operatorname{chi} 2(90)=3263.79$} \\
\hline
\end{tabular}


Table 6:. Measure of consumption insurance (IV estimation - Second stage estimation provided)

\begin{tabular}{|c|c|c|c|}
\hline First stage & $\Delta$ lpcincome & $\Delta$ lpcincome & $\Delta$ lpcincome \\
\hline \multirow[t]{2}{*}{$\Delta$ mean of lpcincome } & 0.625 & 0.625 & 0.625 \\
\hline & $(30.33) * * *$ & $(30.33)^{* * *}$ & $(30.35) * * *$ \\
\hline \multirow[t]{2}{*}{ Age } & 0.003 & 0.003 & 0.003 \\
\hline & $(0.45)$ & $(0.45)$ & $(0.45)$ \\
\hline \multirow[t]{2}{*}{ Age2 } & 0.000 & 0.000 & 0.000 \\
\hline & $(0.21)$ & $(0.21)$ & $(0.2)$ \\
\hline \multirow[t]{2}{*}{$\Delta$ Femaleshare } & -1.486 & -1.486 & -1.484 \\
\hline & $(4.53)^{* * *}$ & $(4.53)^{* * *}$ & $(4.52)^{* * *}$ \\
\hline \multirow[t]{2}{*}{$\Delta$ Femaleshare2 } & 1.475 & 1.475 & 1.473 \\
\hline & $(4.84)^{* * *}$ & $(4.84)^{* * *}$ & $(4.84)^{* * *}$ \\
\hline \multirow[t]{2}{*}{$\Delta$ Dependency } & -0.013 & -0.013 & -0.014 \\
\hline & $(0.17)$ & $(0.17)$ & $(0.19)$ \\
\hline \multirow{2}{*}{$\Delta$ Seconedushare } & -0.550 & -0.550 & -0.549 \\
\hline & $(5.16)^{* * *}$ & $(5.16)^{* * *}$ & $(5.15)^{* * *}$ \\
\hline \multirow[t]{2}{*}{$\Delta$ Seconedushare2 } & 0.520 & 0.520 & 0.518 \\
\hline & $(5.35)^{* * *}$ & $(5.35)^{* * *}$ & $(5.33)^{* * *}$ \\
\hline \multirow[t]{2}{*}{$\Delta$ no_GS } & -0.008 & -0.008 & -0.008 \\
\hline & $(0.29)$ & $(0.29)$ & $(0.29)$ \\
\hline \multirow[t]{2}{*}{$\Delta$ no_voting } & -0.031 & -0.031 & -0.031 \\
\hline & $(3.32)^{* * *}$ & $(3.32) * * *$ & $(3.33)^{* * *}$ \\
\hline \multirow[t]{2}{*}{$\Delta$ regime_jati } & -0.046 & -0.046 & -0.046 \\
\hline & $(0.73)$ & $(0.73)$ & $(0.74)$ \\
\hline \multirow[t]{2}{*}{$\Delta$ regime_gender } & -0.036 & -0.036 & -0.035 \\
\hline & $(1.29)$ & $(1.29)$ & $(1.27)$ \\
\hline \multirow[t]{2}{*}{$\Delta$ pcasset } & 0.113 & 0.113 & 0.113 \\
\hline & $(15.69) * * *$ & $(15.69) * * *$ & $(15.7)^{* * *}$ \\
\hline \multirow[t]{2}{*}{$(\Delta$ pcasset $) 2$} & -0.001 & -0.001 & -0.001 \\
\hline & $(13.26)^{* * *}$ & $(13.26)^{* * *}$ & $(13.27)^{* * *}$ \\
\hline \multirow[t]{2}{*}{$\Delta$ land_irrigate } & -0.034 & -0.034 & -0.035 \\
\hline & $(0.68)$ & $(0.68)$ & $(0.69)$ \\
\hline \multirow[t]{2}{*}{ Constant } & 0.017 & 0.017 & 0.017 \\
\hline & $(0.09)$ & $(0.09)$ & $(0.09)$ \\
\hline \multirow{2}{*}{ Joint significance } & $\mathrm{F}(15,5141)$ & $\mathrm{F}(15,5140)$ & $\mathrm{F}(15,5139)$ \\
\hline & $=87.41$ & $=87.38$ & $=87.50$ \\
\hline Prob $>F$ & 0.0000 & 0.0000 & 0.0000 \\
\hline Second stage & $\Delta$ lpcex & $\Delta$ lpcex_f & $\Delta \mathrm{lpcex \_ nf}$ \\
\hline \multirow[t]{2}{*}{$\Delta$ lpcincome } & 0.677 & 0.657 & 0.692 \\
\hline & $(13.73) * * *$ & $(13.48)^{* * *}$ & $(11.92) * * *$ \\
\hline \multirow[t]{2}{*}{$\Delta$ mean of lvillpcincome } & -0.431 & -0.406 & -0.45 \\
\hline & $(12.59) * * *$ & $(11.98) * * *$ & $(11.15)^{* * *}$ \\
\hline \multirow[t]{2}{*}{ Age } & 0.004 & 0.004 & 0.004 \\
\hline & $(0.75)$ & $(0.68)$ & $(0.64)$ \\
\hline Age2 & 0 & 0 & 0 \\
\hline & $(0.81)$ & $(0.69)$ & $(0.71)$ \\
\hline$\Delta$ Femaleshare & 0.353 & 0.527 & 0.08 \\
\hline & $(1.29)$ & $(1.95)^{*}$ & $(0.25)$ \\
\hline$\Delta$ Femaleshare2 & -0.489 & -0.601 & -0.288 \\
\hline & $(1.90) *$ & $(2.36)^{* *}$ & $(0.95)$ \\
\hline$\Delta$ Dependency & -0.062 & -0.062 & -0.044 \\
\hline & $(1.08)$ & $(1.09)$ & $(0.64)$ \\
\hline
\end{tabular}




\begin{tabular}{|c|c|c|c|}
\hline$\Delta$ Seconedushare & $\begin{array}{c}0.331 \\
(3.66)^{* * *}\end{array}$ & $\begin{array}{c}0.269 \\
(3.00)^{* * *}\end{array}$ & $\begin{array}{c}0.492 \\
(4.62)^{* * *}\end{array}$ \\
\hline \multirow[t]{2}{*}{$\Delta$ Seconedushare 2} & -0.146 & -0.116 & -0.251 \\
\hline & $(1.75)^{*}$ & $(1.41)$ & $(2.56)^{* *}$ \\
\hline \multirow[t]{2}{*}{$\Delta$ no_GS } & 0.049 & 0.037 & 0.065 \\
\hline & $(2.38) * *$ & $(1.83)^{*}$ & $(2.67)^{* * *}$ \\
\hline \multirow[t]{2}{*}{$\Delta$ no_voting } & 0.014 & 0.021 & 0.002 \\
\hline & $(1.84)^{*}$ & $(2.78) * * *$ & $(0.20)$ \\
\hline \multirow[t]{2}{*}{$\Delta$ regime_jati } & 0.054 & 0.12 & -0.012 \\
\hline & $(1.12)$ & $(2.52) * *$ & $(0.21)$ \\
\hline \multirow[t]{2}{*}{$\Delta$ regime_gender } & 0.059 & 0.065 & 0.055 \\
\hline & $(2.77) * * *$ & $(3.07) * * *$ & $(2.19)^{* *}$ \\
\hline \multirow[t]{2}{*}{ Constant } & -0.267 & -0.327 & -0.199 \\
\hline & $(1.83)$ & $(2.27)$ & $(1.16)$ \\
\hline Observations & 5157 & 5156 & 5155 \\
\hline Joint significance & $\begin{array}{l}\mathrm{F}(13,5143) \\
\quad=22.05\end{array}$ & $\begin{array}{l}\mathrm{F}(13,5142) \\
\quad=20.33\end{array}$ & $\begin{array}{l}\mathrm{F}(13,5141) \\
\quad=1859\end{array}$ \\
\hline Prob $>F$ & 0.0000 & 0.0000 & 0.0000 \\
\hline $\begin{array}{l}\text { Durbin-Wu-Hausman } \\
\text { test of Endogeneity }\end{array}$ & $\operatorname{chi} 2(1)=270.89$ & $\operatorname{chi} 2(1)=241.65$ & $\operatorname{chi} 2(1)=152.26$ \\
\hline Prob $>$ chi 2 & 0.0000 & 0.0000 & 0.0000 \\
\hline $\begin{array}{l}\text { Anderson canonical } \\
\text { correlation LR statistic }\end{array}$ & $\operatorname{chi} 2(3)=241.700$ & $\operatorname{chi} 2(3)=241.653$ & $\operatorname{chi} 2(3)=242.11$ \\
\hline Prob $>$ chi 2 & 0.0000 & 0.0000 & 0.0000 \\
\hline Sargan test statistic & $\operatorname{Chi} 2(2)=2.672$ & Chi2(2) $=3.677$ & Chi2(2) $=2.023$ \\
\hline Prob $>$ chi 2 & 0.2629 & 0.1590 & 0.3637 \\
\hline
\end{tabular}


ASARC Working Paper 2013/12 
Appendix: Summary statistics

\begin{tabular}{|c|c|c|c|c|c|}
\hline Variable & Description & Mean & Std. Dev. & Min & $\operatorname{Max}$ \\
\hline lpcincome & $\log$ (per capita household income) & 8.414 & 0.927 & 2.894 & 12.899 \\
\hline lpcex & $\log$ (per capita HH total consumption expenditure) & 8.602 & 0.508 & 6.494 & 11.394 \\
\hline lpcex $\mathrm{f}$ & $\log$ (per capita HH food consumption expenditure) & 8.044 & 0.466 & 5.783 & 11.061 \\
\hline lpcex_nf & $\log$ (per capita HH non-food consumption expenditure) & 7.685 & 0.661 & 4.534 & 11.276 \\
\hline fhead & 1 if a household is headed by female, otherwise 0 & 0.075 & 0.263 & 0 & 1 \\
\hline age & age of household head & 50.078 & 13.344 & 21 & 100 \\
\hline femaleshare & Share of female members & 0.481 & 0.157 & 0.111 & 1 \\
\hline dependency & Share of household members aged below 14 or above 65 & 0.362 & 0.235 & 0 & 1 \\
\hline seconedushare & Share of household members with high secondary education or higher & 0.437 & 0.372 & 0 & 1 \\
\hline pcasset & per capita number of productive asset including livestocks & 2.132 & 3.016 & 0 & 57 \\
\hline land irrigate & the ratio of the irrigated land to total land size & 0.399 & 0.466 & 0 & 1 \\
\hline no $\overline{\mathrm{GS}}$ & Number of participation in Gram Sabha meetings taken by household members & 0.625 & 0.941 & 0 & 5 \\
\hline no_voting & Number of participation in voting taken by household members & 5.333 & 2.451 & 0 & 11 \\
\hline Pubgoods hh & number of village public goods availablity (per household) & 0.053 & 0.032 & 0.008 & 0.253 \\
\hline lvillpcincome & Log (per capita village income) & 8.511 & 0.481 & 6.873 & 9.762 \\
\hline no_res & 1 if a household is located in avillage never reserved & 0.152 & 0.359 & 0 & 1 \\
\hline once res & 1 if a household is located in avillage once reserved & 0.372 & 0.483 & 0 & 1 \\
\hline no_res & 1 if a household is located in avillage twice reserved & 0.391 & 0.488 & 0 & 1 \\
\hline$\Delta$ regime_jati & 1 if jati of a pradhan was changed & 0.051 & 0.220 & 0 & 1 \\
\hline$\Delta$ regime jati & 1 if gender of a pradhan was changed & 0.474 & 0.499 & 0 & 1 \\
\hline humid* & 1 if a household is located in humid region & 0.299 & 0.458 & 0 & 1 \\
\hline SA temperature* & 1 if a household is located in semi-arid temperature region & 0.244 & 0.430 & 0 & 1 \\
\hline SA_tropic* & 1 if a household is located in semi-arid tropic region & 0.393 & 0.488 & 0 & 1 \\
\hline $\operatorname{arid*}$ & 1 if a household is located in arid region & 0.152 & 0.246 & 0 & 1 \\
\hline \multicolumn{6}{|c|}{ Shock variables (Dummy) } \\
\hline covariate & 1 if a household was affected by either drought, floods, epidemic or livestock epidemic & 0.369 & 0.483 & 0 & 1 \\
\hline drought & 1 if a household was affected by drought & 0.222 & 0.415 & 0 & 1 \\
\hline floods & 1 if a household was affected by floods & 0.154 & 0.361 & 0 & 1 \\
\hline epidemic & 1 if a household was affected by epidemic & 0.035 & 0.184 & 0 & 1 \\
\hline livestk & 1 if a household was affected by livestock epidemic & 0.040 & 0.195 & 0 & 1 \\
\hline
\end{tabular}




\begin{tabular}{|c|c|c|c|c|c|}
\hline idiosyncratic & 1 if a household was affected by death of $\mathrm{HH}$ members, sudden health problem or crop failure & 0.326 & 0.469 & 0 & 1 \\
\hline death & 1 if a household was affected by death of HH members & 0.065 & 0.246 & 0 & 1 \\
\hline health & 1 if a household was affected by sudden health problem & 0.083 & 0.275 & 0 & 1 \\
\hline crop failure & 1 if a household was affected by crop failure & 0.105 & 0.307 & 0 & 1 \\
\hline \multicolumn{6}{|c|}{ Coping strategy (Dummy) } \\
\hline saving & 1 if a household used its own saving for risk coping purpose & 0.346 & 0.476 & 0 & 1 \\
\hline govt & 1 if a household used the government programme for risk coping purpose & 0.045 & 0.208 & 0 & 1 \\
\hline transfer & $\begin{array}{l}1 \text { if a household used borrowing or transfer from relatives/friends } \\
\text { for risk coping purpose }\end{array}$ & 0.088 & 0.284 & 0 & 1 \\
\hline Capital depletion & $\begin{array}{l}1 \text { if a household depleted physical and human capital, reduced consumption } \\
\text { or changed crop choice for risk coping purpose }\end{array}$ & 0.088 & 0.283 & 0 & 1 \\
\hline other & 1 if a household used other strategies for risk coping purpose & 0.498 & 0.500 & 0 & 1 \\
\hline
\end{tabular}

The number of observations in the household characteristics is 10830 (5415 HHs for each year).

The variables for shocks and coping strategy are available from 2006 survey and the number of observations is 5559 .

*: ICRISAT categorisation of agro-climatic condition

Humid - Length of Growing Period (LGP) $>180$ days

Semi-Arid temperature - LGP: $75-180$ days, Temp $<=18$ degree

Semi-Arid tropic - LGP: 75-180 days, Temp $>=18$ degree

Arid - LGP $<75$ days 
ASARC Working Paper 2013/12 